\title{
CONTACT TOXICITY OF ESSENTIAL OIL OF Croton pulegiodorus BAILL ON Sitophilus zeamais MOTSCHULSKY ${ }^{1}$
}

\author{
PATRYCK ÉRMERSON MONTEIRO DOS SANTOS ${ }^{2 *}$, ANTONIELSON BEZERRA DA SILVA ${ }^{2}$, CILENE REJANE \\ INÁCIO DE MAGALHÃES LIRA ${ }^{3}$, CLÁUDIA HELENA CYSNEIROS MATOS ${ }^{2}$, CARLOS ROMERO FERREIRA DE \\ OLIVEIRA $^{2}$
}

\begin{abstract}
The objective of this work was to evaluate the contact toxicity of essential oil of Croton pulegiodorus Baill on six populations of Sitophilus zeamais Motschulsky. The S. zeamais populations used were from Crixás-GO, Espírito Santo do Pinhal-SP, Juiz de Fora-MG, Picos-PI, Serra Talhada-PE, and Vicentina-MS, Brazil, and present different susceptibility to synthetic insecticides. The essential oil of $C$. pulegiodorus used was obtained from plants collected in Triunfo-PE, Brazil. The lethal concentrations $\left(\mathrm{LC}_{50}\right.$ and $\mathrm{LC}_{90}$ ), toxicity ratio of the essential oil, and the resistance ratio of the populations were estimated. The $S$. zeamais population from Serra Talhada-PE presented the lowest $\mathrm{LC}_{50}\left(\begin{array}{llllll}4.21 & \mu \mathrm{L} & 20 & \mathrm{~g}^{-1}\end{array}\right)$ and $\mathrm{LC}_{90}$ $\left(6.67 \mu \mathrm{L} 20 \mathrm{~g}^{-1}\right)$, and was the reference for susceptibility to the essential oil of C. pulegiodorus. The $S$. zeamais population from Espírito Santo do Pinhal-SP presented the highest $\mathrm{LC}_{50}\left(\begin{array}{ccccc}6.02 & \mu \mathrm{L} & 20 & \mathrm{~g}^{-1}\end{array}\right)$ and $\mathrm{LC}_{90}$

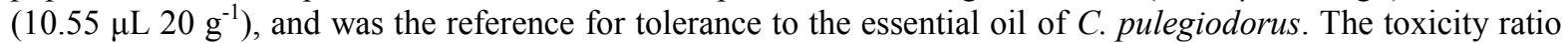
ranged from 1.01 (Picos-PI) to 1.43 (Serra Talhada-PE); and the resistance ratio ranged from 1.13 (Crixás-GO) to 1.43 (Espírito Santo do Pinhal-SP). The essential oil of $C$. pulegiodorus reduced the emergence of adult $S$. zemais and showed residual effect, with contact toxicity, after 30 and 60 days of application.
\end{abstract}

Keywords: Botanical insecticides. Euphorbiaceae. Maize storage. Curculionidae.

\section{TOXICIDADE POR CONTATO DO ÓLEO ESSENCIAL DE Croton pulegiodorus BAILL SOBRE Sitophilus zeamais MOTSCHULSKY}

\begin{abstract}
RESUMO - O objetivo do presente estudo foi avaliar a toxicidade por contato do óleo essencial de Croton pulegiodorus Baill sobre seis populações de Sitophilus zeamais Motschulsky. As populações de S. zeamais utilizadas apresentam diferentes padrões de susceptibilidade a inseticidas sintéticos e foram provenientes dos municípios de Crixás - GO, Espírito Santo do Pinhal - SP, Juiz de Fora - MG, Picos - PI, Serra Talhada - PE e Vicentina - MT. O óleo essencial foi obtido a partir de plantas coletadas no município de Triunfo - PE, sendo estimadas as concentrações letais $\left(\mathrm{CL}_{50}\right.$ e $\left.\mathrm{CL}_{90}\right)$, as razões de toxicidade $(\mathrm{RT})$ e as razões de resistência (RR) das populações. A população de Serra Talhada - PE apresentou as menores $\mathrm{CL}_{50}(4,21 \mu \mathrm{L} / 20 \mathrm{~g}$ de milho) e $\mathrm{CL}_{90}(6,67 \mu \mathrm{L} / 20 \mathrm{~g}$ de milho), sendo considerada padrão de susceptibilidade ao óleo essencial de $C$. pulegiodorus. Por outro lado, a população de Espírito Santo do Pinhal - SP apresentou as maiores $\mathrm{CL}_{50}(6,02$ $\mu \mathrm{L} / 20 \mathrm{~g}$ de milho) e $\mathrm{CL}_{90}(10,55 \mu \mathrm{L} / 20 \mathrm{~g}$ de milho), sendo considerada padrão de tolerância ao óleo. A razão de toxicidade (RT) variou de 1,01 vezes (Picos - PI) a 1,43 vezes (Serra Talhada - PE) enquanto que a razão de resistência (RR) variou de 1,13 vezes (Crixás - GO) a 1,43 vezes (Espírito Santo do Pinhal - SP). Observou-se que o óleo essencial de $C$. pulegiodorus ocasionou redução na emergência de adultos de $S$. zemais e apresentou efeito residual, pela via de contato, após 30 e 60 dias de aplicação.
\end{abstract}

Palavras-chaves: Inseticidas botânicos. Euphorbiaceae. Milho armazenado. Curculionidae.

\footnotetext{
${ }^{*}$ Corresponding author

${ }^{1}$ Received for publication in 08/31/2018; accepted in 02/26/2019.

Paper approved from III SINPROVS 2018.

Paper extracted from the course conclusion monograph of the first author.

${ }^{2}$ Academic Unit of Serra Talhada, Universidade Federal Rural de Pernambuco, Serra Talhada, PE, Brazil; patryckermerson@gmail.com - ORCID: 0000-0001-9526-2465, antonielsonbezerra@hotmail.com - ORCID: 0000-0001-7798-4077, claudia.matos@ufrpe.br - ORCID: 0000-0001-6467-8177, carlos.foliveira@ufrpe.br - ORCID: 0000-0001-8250-6344.

${ }^{3}$ Department of Biochemistry, Universidade Federal de Pernambuco, Recife, PE, Brazil; cilenerejane@hotmail.com - ORCID: 0000-00034873-7442.
} 


\section{INTRODUCTION}

Maize (Zea mays L.) is an important grain crop in Brazil. The Brazilian maize grain production in the $2017 / 2018$ crop season is estimated in more than 82 million of tonnes (CONAB, 2018). Despite the high productivity of this crop, significant losses during grain storage occur due to several factors, including the attack of insect pests, such as Sitophilus zeamais Motschulsky (Coleoptera: Curculionidae) (LIMA JUNIOR et al., 2012), which is one of the main insect pest of stored grains, especially cereal (COITINHO et al., 2011), and causes quantitative and qualitative damages (ALONSO-AMELOT; AVILA-NÚNEZ, 2011; SILVA et al., 2012a; MIKAMI; CARPENTIERIPÍPOLO; VENTURA, 2012).

Problems caused by synthetic insecticides and fumigants, which are used to control pests of stored products, include risks to the environment and human health and the emergence of resistant insect populations to their active principles, and have led to the search for alternative methods of control (GUEDES, GUEDES; ROSI-DENADAI, 2011). Therefore, several resistant insect populations that attack stored products have been found, especially of S. zeamais (SOUSA et al., 2009; PIMENTEL et al., 2009; BOYER et al., 2012).

Studies have shown the potential of using essential oils as an alternative method for seed protection and control of several pests of stored products in Brazil (COITINHO et al, 2011; BRITO et al, 2015; MAGALHÃES et al, 2015; SOUZA et al, 2016; ARAÚJO et al., 2017). Essential oils present different effects on insects (SUTHISUT; FIELDS; CHANDRAPATYA, 2011; KŁYS; MALEJKY; NOWAK-CHMURA, 2017), causing biochemical, physiological, and behavioral disorders that lead to their death or affect their development and reproduction (CABALLERO-GALLARDO; OLIVERO-VERBEL; STASHENKO, 2011, CHAUBEY, 2016).

Several species of the Croton genus (Euphorbiaceae) have been evaluated due to their insecticidal potential on coleoptera and lepidoptera pests of stored products (SILVA et al., 2009; SILVA et al., 2012b; CARVALHO et al., 2016). The fumigant and repellent effects of the essential oil of Croton pulegiodorus Baill were recently proven on pests of stored common bean and maize grains (BRITO et al., 2015; MAGALHÃES et al., 2015; SOUZA et al., 2016).

The objective of the present study was to evaluate the contact and ingestion toxicity and the residual effect of the essential oil of $C$. pulegiodorus on $S$. zeamais populations from different regions of Brazil, which present different susceptibility to synthetic insecticides. As a result, this study aimed to answer the following questions: (i) is the effect of the essential oil of $C$. pulegiodorus different on the different populations of $S$. zeamais? (ii) do the $S$. zeamais populations that have shown resistance to pyrethroid and organophosphate insecticides are also more tolerant to the essential oil of $C$. pulegiodorus? (iii) does the insecticidal action of the essential oil of C. pulegiodorus persists during the storage of treated grains?

\section{MATERIAL AND METHODS}

The experiments were conducted at the Arthropod Ecology Center (NEA) and the Laboratory of the Postgraduate Program in Plant Production, of the Academic Unit of Serra Talhada (UAST), at the Federal Rural University of Pernambuco (UFRPE), in Brazil.

Six $S$. zeamais populations that had different susceptibility to synthetic insecticides were used. These populations were from Crixás-GO, Espírito Santo do Pinhal-SP, Juiz de Fora-MG, Picos-PI, Serra Talhada-PE, and Vicentina-MS; they were established in laboratory conditions without any exposure to insecticides. Some of these populations had already been evaluated in previous studies on resistance to synthetic insecticides (CORRÊA, 2009); the population from Juiz de Fora-MG presented moderate to high resistance, the population from Espírito Santo do Pinhal-SP presented moderate resistance, and the population from Vicentina-MS presented susceptibility to the synthetic insecticides tested. The insect populations were maintained in laboratory conditions on clean dry maize grains, packed in plastic bottles with perforated plastic lids that were covered with organza-fabric to allow gas exchanges. The populations were kept in Biochemical Oxygen Demand (B.O.D.) chambers at $28 \pm 2{ }^{\circ} \mathrm{C}, 24$-hour scotophase, and relative humidity of $70 \pm 10 \%$.

The plant material (leaves) used to produce the essential oil of C. pulegiodorus was collected in Triunfo (state of Pernambuco, Brazil) in the mornings and from plants at the reproductive stage. Samples of this species were deposited in the Brazilian Semiarid Herbarium (HESBRA) of the UAST-UFRPE (Voucher \#S.S. Matos 104). The leaves were placed in kraft paper bags $(2 \mathrm{~kg})$ and dried in an oven at $50{ }^{\circ} \mathrm{C}$ for approximately 48 hours. Then, they were subjected to hydrodistillation for approximately 2 hours in a Clevenger-type apparatus set to obtain an emulsifiable liquid (emulsion); $100 \mathrm{~g}$ of dry leaves and 2.5 liters of distilled water were used for each hydrodistillation.

Then, $100 \mathrm{~mL}$ of dichloromethane solvent $\left(\mathrm{CH}_{2} \mathrm{Cl}_{2}\right)$ were added to $400 \mathrm{~mL}$ of the emulsion with the aid of a separatory funnel, and the reaction formed two phases-oil solvent and water. The funnel was withdrawn and the oil-solvent mixture was separated using a rotary evaporator coupled to a vacuum pump. The essential oil of $C$. pulegiodorus 
obtained was stored in an amber glass at temperature of 6 to $10^{\circ} \mathrm{C}$ to preserve its characteristics.

Preliminary tests of contact and ingestion toxicity were carried out to determine the concentrations that would be used in the experiment. The concentrations to be used were defined as $0,3.5$, $5,6,7.5,10,12.5,15,17.5$, and $20 \mu \mathrm{L}$ of essential oil of $C$. pulegiodorus per $20 \mathrm{~g}$ of maize. The different essential oil concentrations were placed on Petri dishes $(90 \times 15 \mathrm{~mm})$ containing $20 \mathrm{~g}$ of maize grains with the aid of an automatic pipettor, according to the treatments. The Petri dishes were then shaken manually for two minutes and infested with 10 non-sexed adult $S$. zeamais of up to 15 days old.

The containers were kept in a BOD chamber $\left(28 \pm 2{ }^{\circ} \mathrm{C}\right.$, and $\left.70 \pm 10 \% \mathrm{RH}\right)$ and the insect mortality percentages were determined after 48 hours. The results were subjected to Probit analysis to estimate the lethal concentrations for each $S$. zeamais population $\left(\mathrm{LC}_{50}\right.$ and $\left.\mathrm{LC}_{90}\right)$ - concentrations of the essential oil necessary to kill $50 \%$ and $90 \%$ of the insects. The toxicity ratio (TR) for $\mathrm{LC}_{50}$ and $\mathrm{LC}_{90}$ was calculated by dividing the highest value of $\mathrm{LC}_{50}$ or $\mathrm{LC}_{90}$ by the values found in each of the remaining populations. Resistance ratios (RR) were calculated by dividing each value of $\mathrm{LC}_{50}$ by the lowest value found, i.e., the $\mathrm{LC}_{50}$ of each population by the $\mathrm{LC}_{50}$ of the population considered most susceptible (reference population). These ratios are considered significant when $95 \%$ confidence intervals do not include the 1.0 value (ROBERTSON; PREISLER, 1992). The experiments were conducted individually for each $S$. zeamais population, using a completely randomized design with 10 treatments (concentrations) and five replications.

The emergence of $S$. zeamais in maize grains under effect of the essential oil of $C$. pulegiodorus was evaluated using different concentrations $(0,3.5$, $4.5,5.5$, and $\left.6.5 \mu \mathrm{L} 20 \mathrm{~g}^{-1}\right)$ that were defined by preliminary tests on each insect population. Twenty grams of maize were placed on Petri dishes $(90 \times 15$ $\mathrm{mm}$ ) and the different concentrations of the essential oil of $C$. pulegiodorus were added with the aid of an automatic pipettor. The plates were then shaken manually for two minutes, and 20 non-sexed adult $S$. zeamais insects were added and kept for 72 hours on the plates to perform oviposition. The insects were then removed and the grains were placed in $100 \mathrm{ml}$ plastic pots. The number of emerged insects was evaluated at 30 days after the experiment implementation, using a completely randomized design with five treatments (concentrations) and five replications.

The residual effect of the essential oil of $C$. pulegiodorus on maize grains was evaluated by simulating different storage periods $(30$ and 60 days). The essential oil was evaluated at concentrations equivalent to the lethal concentrations $\left(\mathrm{LC}_{50}\right.$ and $\left.\mathrm{LC}_{90}\right)$ found for each $S$. zeamais population. The lethal concentrations of the essential oil were added to Petri dishes containing $20 \mathrm{~g}$ of maize grains with the aid of an automatic pipettor.

The treated grains were then stored in glass flasks $(250 \mathrm{~mL})$ for 30 and 60 days and subsequently transferred to $100 \mathrm{~mL}$ plastic pots infested with 20 non-sexed adult $S$. zeamais to evaluate the residual effect of the oil concentrations on them. The insects were kept on the grains for 72 hours for oviposition and, then, they were removed; and the grains were stored again for another 30 days. Subsequently, the number of insects emerged from these treated grains was counted. The experiment was evaluated using a completely randomized design with three treatments (lethal concentrations of the oil and a control), two storage periods (30 and 60 days), and five replications. The results were subjected to analysis of variance and the means were compared by the Tukey's test $(p \leq 0.05)$.

\section{RESULTS AND DISCUSSION}

The lethal concentrations $\left(\mathrm{LC}_{50}\right.$ and $\left.\mathrm{LC}_{90}\right)$ of the essential oil of $C$. pulegiodorus for the $S$. zeamais populations is shown in Table 1; the responses of the $S$. zeamais populations to the essential oil varied. The population from Espírito Santo do Pinhal-SP presented the highest $\mathrm{LC}_{50}\left(6.02 \mu \mathrm{L} 20 \mathrm{~g}^{-1}\right)$, and the one from Serra Talhada-PE presented the lowest

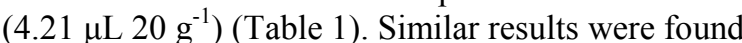
for $\mathrm{LC}_{90}$; the population from Espírito Santo do Pinhal-SP presented the highest $\mathrm{LC}_{90}(10.55 \mu \mathrm{L} 20 \mathrm{~g}$ $\left.{ }^{1}\right)$ and the one from Serra Talhada-PE the lowest

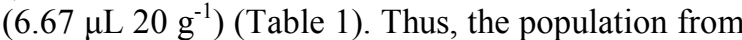
Serra Talhada-PE was the reference for susceptibility to the essential oil of $C$. pulegiodorus, and the one from Espírito Santo do Pinhal-SP was the reference for tolerance to this oil.

The toxicity ratio based on the $\mathrm{LC}_{50}$ varied from 1.01 for the population from Picos-PI to 1.43 for the one from Serra Talhada-PE (Table 1). Similarly, the toxicity ratio based on the $\mathrm{LC}_{90}$ varied from 1.15 for the population from Picos-PI to 1.85 for the one from Serra Talhada-PE (Table 1). The population from Serra Talhada-PE presented the highest toxicity ratio for both LCs, thus, the essential oil of $C$. pulegiodorus had greater toxicity on this population, denoting that this population is more susceptible to the essential oil than the other evaluated populations.

The resistance ratio based on the $\mathrm{LC}_{50}$ varied from 1.13 for the population from Crixás-GO to 1.43 for the population from Espírito Santo do Pinhal-SP. The other populations did not include the value 1.0 in the confidence intervals (ROBERTSON; PREISLER, 1992), except that from Serra Talhada$P E$, showing significant resistance ratios to the essential oil of $C$. pulegiodorus, even though low values were found. 
The resistance ratios found for the populations through contact with the essential oil of C. pulegiodorus were slightly lower than those found for the $S$. zeamais populations evaluated by Silva (2017) through fumigation. The author used populations from Bom Conselho-PE, Garanhuns-PE, Jupi-PE, Lajedo-PE, São João-PE, Serra Talhada-PE, Sete Lagoas-MG, and Jacarezinho-PR, Brazil, and found resistances of 1.84 (São João-PE) to 4.26 (Jupi -PE). However, the resistance of these populations to this oil was low, which was below their resistance to synthetic insecticides, considering that a resistance ratio greater than 10.0 represents a critical resistance, from which the product used can be compromised.

Kirk et al. (2013) showed that the selection pressures of various agroecosystems can affect the genetics of populations. Pest control carried out exclusively with synthetic insecticides can lead to specific changes in DNA, causing behavioral changes and selecting individuals with a certain genetic profile. This process can lead to failures in control, and emergence of resistant populations. In addition, insect populations may remain resistant to certain insecticides for long periods, even without exposure to them (CORRÊA et al., 2008). Therefore, the determination of the $\mathrm{LC}_{50}$ and resistance ratio assists on following of the temporal changes in the susceptibility of the populations. These studies are important because they provide information on how different pest species, or a single species (in this case $S$. zemais) from different localities, behave when exposed to grain and seed protection products.

This behavior was expected for the population from Serra Talhada-PE, in which the lowest $\mathrm{LC}_{50}$ and $\mathrm{LC}_{90}$ was found; the selection pressure in this $S$. zeamais population was probably lower, affecting the results of the oil used. Studies showed that the use of insecticides in Pernambuco has been carried inadequately or with incorrect dosages, favoring the selection of resistant individuals in these populations. Other populations of $S$. zeamais from Pernambuco showed high levels of resistance to pyrethroids (MELO JUNIOR et al., 2018), indicating possible failures in pest control in the state.

A population from Juiz de Fora showed high resistance to several synthetic insecticides, probably due to the high detoxification capacity of these individuals, which may present insensitivity of sites of action as a resistance mechanism to synthetic insecticides (CORRÊA, 2009). In addition, this population was relatively tolerant to the essential oil of $C$. pulegiodorus in the present study, however, the highest lethal concentrations $\left(\mathrm{LC}_{50}\right.$ and $\left.\mathrm{LC}_{90}\right)$ was found for the population from Espírito Santo do Pinhal-SP. This was not expected, since insects from this region were shown to be relatively susceptible to synthetic insecticides in previous studies (CORRÊA, 2009; HADDI et al., 2015).

These results point out the importance of evaluating the feasibility of alternative methods of control of stored grain pests, including the use of essential oils combined with fumigants or synthetic insecticides usually used. Some studies on Brazilian populations of $S$. zeamais that have showed resistance to insecticides and fumigants have also shown high tolerance or susceptibility to essential oils (PIMENTEL, 2009; ARAÚJO et al., 2017), indicating a high plasticity of these insect populations.

Table 1. Toxicity of essential oil of Croton pulegiodorus on populations of Sitophilus zeamais by contact and ingestion in laboratory conditions (temperature of $28 \pm 2{ }^{\circ} \mathrm{C}$, relative humidity of $70 \pm 10 \%$, and scotophase of 24 hours).

\begin{tabular}{|c|c|c|c|c|c|c|c|c|}
\hline POPULATION & $\mathrm{N}$ & $\begin{array}{c}\left(\mathrm{LC}_{50} \mu \mathrm{L} / 20 \mathrm{~g}\right. \\
\text { of maize) } \\
\text { (C.I. 95\%) }\end{array}$ & $\begin{array}{c}\left(\mathrm{LC}_{90} \mu \mathrm{L} / 20 \mathrm{~g}\right. \\
\text { of maize) } \\
\text { (C.I. 95\%) }\end{array}$ & DG & $\chi^{2}$ & $\mathrm{TR}_{50}$ & $\mathrm{TR}_{90}$ & $\begin{array}{c}\mathrm{RR} \\
\mathrm{CL}_{50} \\
\text { (C.I. } 95 \%)\end{array}$ \\
\hline $\begin{array}{c}\text { Espírito Santo do } \\
\text { Pinhal - SP }\end{array}$ & 500 & $\begin{array}{c}6.02 \\
(5.23-6.77)\end{array}$ & $\begin{array}{c}10.55 \\
(9.14-13.14)\end{array}$ & 43 & 113.98 & - & - & $\begin{array}{c}1.43 \\
(1.37-1.49)\end{array}$ \\
\hline Picos - PI & 500 & $\begin{array}{c}5.95 \\
(5.49-6.42)\end{array}$ & $\begin{array}{c}9.16 \\
(8.28-10.58)\end{array}$ & 43 & 63.89 & 1.01 & 1.15 & $\begin{array}{c}1.41 \\
(1.36-1.47)\end{array}$ \\
\hline Vicentina - MT & 500 & $\begin{array}{c}5.66 \\
(5.33-5.99)\end{array}$ & $\begin{array}{c}8.32 \\
(7.69-9.26)\end{array}$ & 43 & 39.63 & 1.06 & 1.27 & $\begin{array}{c}1.34 \\
(1.30-1.39)\end{array}$ \\
\hline Juiz de Fora - MG & 500 & $\begin{array}{c}5.21 \\
(4.75-5.63)\end{array}$ & $\begin{array}{c}8.01 \\
(7.26-9.25)\end{array}$ & 43 & 62.44 & 1.15 & 1.32 & $\begin{array}{c}1.21 \\
(1.24-1.27)\end{array}$ \\
\hline Crixás - GO & 500 & $\begin{array}{c}4.76 \\
(4.03-5.39)\end{array}$ & $\begin{array}{c}9.13 \\
(7.98-11.12)\end{array}$ & 43 & 79.22 & 1.26 & 1.16 & $\begin{array}{c}1.13 \\
(1.11-1.15)\end{array}$ \\
\hline Serra Talhada - PE & 500 & $\begin{array}{c}4.21 \\
(3.81-4.54)\end{array}$ & $\begin{array}{c}6.67 \\
(6.12-7.51)\end{array}$ & 43 & 45.74 & 1.43 & 1.58 & - \\
\hline
\end{tabular}

$\mathrm{N}=$ Total number of inscets; $\mathrm{LC}=$ lethal concentration; $\mathrm{C}$. I.= confidence interval; $\mathrm{DG}=$ degrees of freedom; $\chi^{2}=\mathrm{Chi}-$ square; TR $=$ Toxicity ratio was calculated by dividing the highest $\mathrm{LC}_{50}$ or $\mathrm{LC}_{90}$ by the values found in each of the populations; $\mathrm{RR}(95 \% \mathrm{CI})=$ Resistance ratio calculated by dividing the $\mathrm{LC}_{50}$ of the study population by the $\mathrm{LC}_{50}$ of the susceptibility pattern population and confidence intervals at $95 \%$ probability; Population of $S$. zeamais that showed a significant resistance ratio by method of Robertson; Preisler (1992). 
The residual effect of the essential oil of $C$. pulegiodorus on $S$. zeamais populations showed no significant effect of the storage period (30 and 60 days) on the emergence of adult $S$. zeamais. However, the essential oil had effect on the populations Crixás-GO $(\mathrm{F}=15.5544$ and $p<0.00005)$, Espírito Santo do Pinhal-SP $(\mathrm{F}=6.5822$ and $p<0.00526)$, Juiz de Fora-MG $(\mathrm{F}=3.44$ and $p<0.0487)$, Picos-PI $(\mathrm{F}=13.3214$ and $p<0.00013)$, and Vicentina-MS (9.7197 and $p<0.00081)$, except the one from Serra Talhada-PE, in which the result of the treatments, and their comparison with the control $(\mathrm{F}=1.7231$ and $p<0.199874)$ did not differ.
The effect of the essential oil of $C$. pulegiodorus on $S$. zemais populations showed that the number of emerged insects did not differ significantly between the tested lethal concentrations ( $\mathrm{LC}_{50}$ and $\mathrm{LC}_{90}$ ), but differed from the control, with significant reduction in the number of emerged adults (Figure 1). This shows that the essential oil of $C$. pulegiodorus has a residual effect on $S$. zeamais, even after 60 days of storage of treated maize grains. The $\mathrm{LC}_{50}$ of this oil for the control of $S$. zeamais is recommended because both lethal concentrations had a similar effect on insect emergence, presenting the same efficiency with less essential oil.
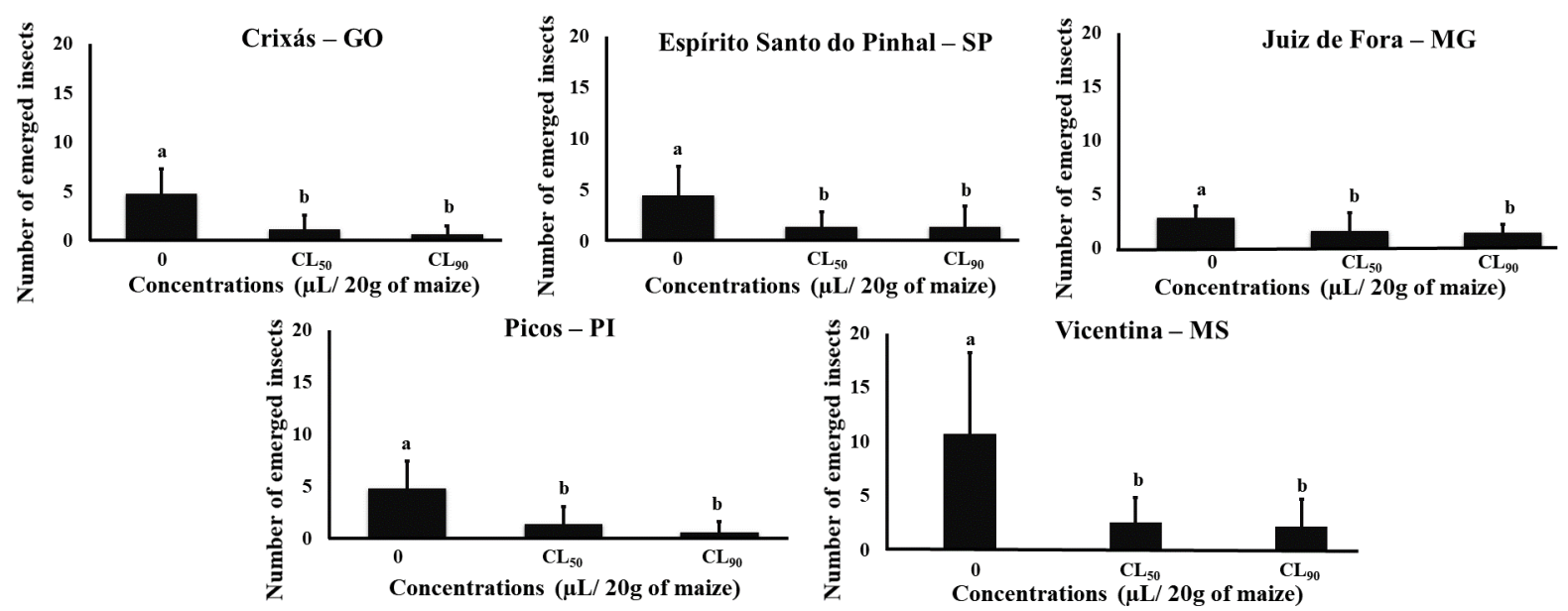

Figure 1. Emergence of adult Sitophilus zeamais in stored maize grains treated with lethal concentrations (LC) of essential oil of Croton pulegiodorus in laboratory conditions (temperature of $28 \pm 2{ }^{\circ} \mathrm{C}$, relative humidity of $70 \pm 10 \%$, and scotophase of 24 hours). Bars followed by the same letter do not differ by the Tukey's test at $5 \%$ probability.

The persistence of the insecticidal activity of the essential oil of $C$. pulegiodorus found in the present study is important for the control of $S$. zeamais in stored maize, since this information contributes for the determination of the minimum interval required for the application of this natural insecticide. In general, essential oils have limited persistence; some studies have evaluated these aspects. Coitinho et al. (2006) evaluated the residual effect of essential oils of Eucalyptus globulus Labill (Myrtaceae), Lippia gracilis Schauer (Verbenaceae), Azadirachta indica A. Juss (Meliaceae), and Caryocar brasiliense Camb. (Caryocareceae) and found that they caused $100 \%$ mortality of adult $S$. zeamais at the initial storage period (soon after impregnation); however, after 60 and 120 days of storage, the mortality of the insects was inexpressive. Zewde and Jember (2010) evaluated essential oil of Citrus sinensis L. obtained from fresh fruits on populations of Zabrotes subfasciatus Bohemann, 1833 (Coleoptera: Bruchidae) and found a decrease in mortality after 24 hours, denoting a low residual effect of the essential oil. Coitinho et al. (2010) evaluated the persistence of essential oils of Piper hispidinervum C. DC (Piperaceae), Piper marginatum Jacq. (Myrtaceae), and Schinus terebinthifolius Raddi (Anacardiaceae) with storage periods of 0 to 120 days and found mortality of 93 to $100 \%$ in S. zeamais for all essential oils, with decreasing effect to maximum values of $14.1 \%$ after 30 days, and $4.7 \%$ after 90 days of storage; the exception was the essential oil of $P$. marginatum, which presented mortality above $90 \%$ at $0,30,60$, and 90 days, and $53.1 \%$ mortality after 120 days of storage.

Studies have shown that essential oils affect the emergence and, consequently, the population growth of insects of stored products. Tapondjou et al. (2005) evaluated the bioactivity of essential oils of Cupressus sempervirens L. (Cupressaceae) and Eucalyptus saligna L'Héritier (Myrtaceae) on $S$. zeamais and found that they reduced the emergence of adult insects.

Brito et al. (2015) evaluated essential oils of Croton heliotropiifolius Kunth (Euphorbiaceae), $C$. pulegiodorus, and Myracrodruon urundeuva Allemão (Anacardiaceae) on coleoptera pests of stored common bean and found a reduction in adult emergence through ovicidal/larvicidal effect. Similarly, Magalhães et al. (2015) reported that essential oils of $C$. pulegiodorus and $C$. heliotropiifolius caused $100 \%$ reduction in emergence of $T$. castaneum in stored maize. 


\section{CONCLUSIONS}

The Sitophilus zeamais populations presented different behaviors when subjected to contact and ingestion of essential oil of Croton pulegiodorus.

The $S$. zeamais population from Espírito Santo do Pinhal-SP was the most tolerant to essential oil of C. pulegiodorus; and the insect population from Serra Talhada-PE was the most susceptible to this essential oil.

The essential oil of $C$. pulegiodorus, at the concentrations evaluated, showed an insecticidal effect on $S$. zeamais populations, even after 60 days of storage, significantly reducing the emergence of adults in the evaluated populations.

\section{REFERENCES}

ALONSO-AMELOT, M.; AVILA-NÚNEZ, J. Comparison of seven methods for stored cereal losses to insects for their application in rural conditions. Journal of Stored Products Research, v. 47 , n. 2, p. 82-87. 2011.

ARAÚJO, A. M. N. et al. Lethal and sublethal responses of Sitophilus zeamais populations to essential oils. Journal of Pest Science, v. 90, n. 2, p. $589-600,2017$.

BOYER, S. et al. A review of control methods and resistance mechanisms in stored-product insects. Bulletin of Entomological Research, v. 102, n. 2, p. 213-229, 2012.

BRITO, S. S. S. et al. Bioatividade de óleos essenciais sobre Zabrotes subfasciatus Boh. (Coleoptera: Chrysomelidae) em feijão-comum armazenado. Agrária - Revista Brasileira de Ciências Agrárias, v. 10, n. 2, p. 243-248, 2015.

CABALLERO-GALLARDO, K.; OLIVEROVERBEL, J. STASHENKO, E. E. Repellent Activity of Essential Oils and Some of Their Individual Constituents against Tribolium castaneum Herbst. Journal of Agricultural And Food Chemistry, v. 56, n. 5, p. 1690-1690, 2011.

CARVALHO, G. S. et al., Insecticidal activity of plant extracts and essential oils of bleed water against the bean weevil. Journal of Stored Products and Postharvest Research, v. 7, n. 7, p. 69-75. 2016.

CHAUBEY, M. K. Fumigant and contact toxicity of Allium sativum (Alliaceae) essential oil against Sitophilus oryzae L. (Coleoptera: Dryophthoridae). Entomology and Applied Science Letters, v. 3, n. 2, p. 43-48, 2016.
COITINHO, R. L. B. C. et al. Atividade inseticida de óleos vegetais sobre Sitophilus zeamais Mots. (Coleoptera: Curculionidae) em milho armazenado. Revista Caatinga, v. 19, n. 2, p. 176-182, 2006.

COITINHO, R. L. B. C. et al. Persistência de óleos essenciais em milho armazenado, submetido à infestação de gorgulho do milho. Ciência Rural, v. 40, n. 7 , p. 1-5, 2010.

COITINHO, R. L. B. C. et al. Toxicidade por fumigação, contato e ingestão de óleos essenciais para Sitophilus zeamais Motschulsky, 1885 (Coleoptera: Curculionidae). Ciência e Agrotecnologia, v. 35, n. 1, p. 172-178, 2011.

COMPANHIA

NACIONAL

DE ABASTECIMENTO - CONAB. Acompanhamento da safra nacional de grãos 2017/2018. Décimo primeiro levantamento, 2018.

CORRÊA, A. S. Resistência fisiológica e comportamental de populações de Sitophilus zeamais a permetrina, esfenvalerato e esfenvalerato+ fenitrotiona. 2009. 65 f. Dissertação (Mestrado em Entomologia: Área de Concentração em Entomologia Agrícola) - Universidade Federal de Viçosa, Viçosa, 2009.

CORRÊA, A. S. et al. Custo adaptativo da resistência através da competição entre populações susceptíveis de Sitophilus zeamais (Coleoptera: Curculionidae) e resistentes a piretróides. Revista Brasileira de Armazenamento, v. 33, n. 2, p. 1928, 2008.

GUEDES R. N. C.; GUEDES, N. M. P.; ROSIDENADAI, R, A. Sub-lethal effects of insecticides on stored-product insects: current knowledge and future needs. Stewart Postharvest Review, v. 5, n. 3 , p. $1-5,2011$.

HADDI, K. et al. Metabolic and behavioral mechanisms of indoxacarb resistance in Sitophilus zeamais (Coleoptera: Curculionidae). Journal of Economic Entomology, v. 108, n. 1, p. 362-369, 2015.

KIRK, H.; DORN, S.; MAZZI, D. Molecular genetics and genomics generate new insights into invertebrate pest invasions. Evolutionary Applications, v. 6, n. 5, p. 842-856, 2013.

KŁYS, M.; MALEJKY, N.; NOWAK-CHMURA, $M$. The repellent effect of plants and their active substances against the beetle storage pests. Journal of Stored Products Research, v. 72, n. 1, p. 66-77, 2017. 
LIMA JÚNIOR, A. F. et al. M. Controle de pragas de grãos armazenados: uso e aplicação de fosfetos. Revista Faculdade Montes Belos, v. 5, n. 4, p. 180184, 2012.

MAGALHÃES, C. et al. Potencial inseticida de óleos essenciais sobre Tribolium castaneum em milho armazenado. Revista Brasileira de Plantas Medicinais, v. 17, n. 4, p. 1150-1158, 2015.

MELO JÚNIOR, J. L. A. et al. Insecticide resistance of corn weevil populations from semi-arid regions. Australian Journal of Crop Science, v. 12, n. 3, p. $430-434,2018$.

MIKAMI, A. Y.; CARPENTIERI-PÍPOLO, V.; VENTURA, M. U. Resistance of Maize Landraces to the Maize Weevil Sitophilus zeamais Mots. (Coleoptera: Curculionidae). Neotropical Entomology, v. 41, n. 5, p. 404-408, 2012.

PIMENTEL, M. A. G. et al. Phosphine resistance in Brazilian populations of Sitophilus zeamais Motschusky (Coleoptera: Curculionidae). Journal of Stored Products Research, v. 45, n. 1, p. 71-74, 2009.

ROBERTSON, J. L; PREISleR, H. K. Pesticide bioassays with arthropods. 1. ed. Boca Raton, FL: CRC Press, 1992.127 p.

SILVA, J. F. et al. Bioatividade do extrato de Momordica charantia L. sobre Sitophilus zeamais Motschulsky 1885 (Coleoptera: Curculionidae). Revista Verde de Agroecologia e Desenvolvimento Sustentável, v. 7, n. 2, p. 179-183, 2012a.

SILVA, L. B. et al. Effects of Croton urucurana Extracts and Crude Resin on Anagasta kuehniella (Lepidoptera: Pyralidae). Brazilian Archives of Biology and Technology, v. 52, n. 3, p. 653-664, 2009.

SILVA, L. B. et al. Toxicity of ethanolic extract of Croton heliotropiifolius in weevil populations of stored maize grains. Journal of Entomology, v. 6, n. 3, p. 413-421, 2012 b.

SILVA, T. L. Avaliação do óleo essencial de Croton pulegiodorus Baill sobre populações de Sitophilus zeamais Mots. (Coleoptera: Curculionidae) resistentes a inseticidas sintéticos. (2017). 43 f. Dissertação (Mestrado em Produção Vegetal: Área de Concentração em Produção Vegetal do Semiárido) - Universidade Federal Rural de Pernambuco, Programa de Pós-Graduação em Produção Vegetal, Serra Talhada, PE, 2017. growth rates of phosphine-resistant and susceptible populations of stored product insect pests. Journal of Stored Products Research, v. 45, n. 4, p. 241246, 2009.

SOUZA, V. N. et al. Fumigation toxicity of essential oils against Rhyzopertha dominica (f.) in stored maize grain. Revista Caatinga, v. 29, n. 2, p. 435$450,2016$.

SUTHISUT, D.; FIELDS, P. G.; CHANDRAPATYA, A. Fumigant toxicity of essential oils from three Thai plants (Zingiberaceae) and their major compounds against Sitophilus zeamais, Tribolium castaneum and two parasitoids. Journal of Stored Products Research, v. 47, n. 3, p. 222-230, 2011.

TAPONDJOU, A. et al. Bioactivities of cymol and essential oils of Cupressus sempervirens and Eucalyptus saligna against Sitophilus zeamais Motschulsky and Tribolium confusum du Val. Journal of Stored Products Research, v. 41, n. 1, p. 91-102, 2005.

ZEWDE, D. K.; JEMBERE, B. Evaluation of orange peel citrus sinensis (L.) as a source of repellent, toxicant and protectant against Zabrotes subfasciatus (coleoptera: bruchidae). Mekelle University, v. 2, n. 1, p. $61-75,2010$.

SOUSA, A. et al. Developmental and population 